\title{
EFFECTIVENESS AND ADEQUACY OF WELL SAMPLING USING BAITED TRAPS FOR MONITORING THE DISTRIBUTION AND ABUNDANCE OF AN AQUATIC SUBTERRANEAN ISOPOD
}

\author{
Ben Hutchins ${ }^{1}$ AND William ORNDORFF*,2
}

\begin{abstract}
Land-use practices in karst can threaten aquatic subterranean species (stygobionts). However, since their habitat is mostly inaccessible, baseline ecological data such as distribution and population size are not known, making monitoring and risk assessment difficult. Wells provide easy and inexpensive access for sampling subterranean aquatic habitats. Over three years, including a two-month period of intensive sampling, the authors sampled sixteen wells (ten repeatedly) in Jefferson County, West Virginia, USA, for a threatened stygobiont, the isopod crustacean Antrolana lira Bowman, in two areas where the species was known to occur. A. lira was collected during 21 of 54 sampling events. A. lira was collected from 6 wells in which a total of 31 of the sampling events took place. Borehole logs suggest that only these 6 wells intersected appropriate habitat. Using the binomial approximation, the authors conclude that a random well has a $29 \%$ to $91 \%$ chance of intersecting appropriate habitat. In a well that intersects appropriate habitat, a single sampling event has a $51 \%$ to $85 \%$ chance of successful capture. The species occurs heterogeneously throughout the aquifer both in space and time, and thus, repeated sampling of multiple wells is needed to confidently establish presence or absence. In a contiguous block of phreatic carbonateaquifer habitat analogous to that in the study area, at least 6 wells need to be sampled at least one time each to determine absence or presence of $A$. lira with $95 \%$ confidence. Additional studies with larger sample size would better constrain confidence intervals and facilitate refinement of minimum sampling requirements. In one well that consistently yielded from 8 to 19 animals, the population was estimated by markrecapture methods. The limited data only allowed a very rough result of $112.3 \pm 110$ $(95 \%$ CI $)$ individuals. Successful recapture suggests that animals are largely stationary when a food source is present. Animals were collected at depths below the water surface from $<1 \mathrm{~m}$ (hand-dug well and cave) to $\sim 30$ meters in drilled wells. No migration of animals between wells was observed.
\end{abstract}

DOI: $10.4311 /$ jcks20081sc0037

\section{INTRODUCTION}

The Shenandoah Valley of West Virginia and Virginia is a karst landscape experiencing rapid population growth. Agricultural and urban modification of karst landscapes can lead to contamination and drawdown of karst aquifers, potentially threatening stygobionts (species limited to subterranean aquatic habitats). However, population sizes, ranges, and the distribution of individuals within aquifers is not known for many species, making monitoring and assessment of populations difficult. As international recognition of the significance of groundwater fauna grows, various methods are being developed and tested to sample groundwater habitats and develop predictive models to better understand stygobiont distributions, patterns of abundance, and autecological data (Castellarini et al., 2007, Dole-Oliver et al., 2007, Eberhard et al., 2007, Hancock and Boulton, 2007). For threatened and endangered stygobionts, these data are even more important. The paucity of basic ecological data for most stygobiont species can primarily be attributed to the challenges associated with sampling subterranean habitats. Caves, springs, and wells where biological sampling of karst aquifers is possible are small, isolated points of access into a potentially extensive, complex habitat.

For the majority of stygobionts and troglobionts in the United States, distributional data and population-size estimates have been based on collection efforts in caves (Culver et al., 2003; Fong et al., 2007; Krejca, 2004), while other access points to subterranean habitats, such as springs and wells, have been sampled less thoroughly. However, a large amount of literature demonstrates that

\footnotetext{
${ }^{*}$ Corresponding author

${ }^{1}$ Department of Biology, Texas State University, San Marcos, TX 78666, hutchbt2@yahoo.com

${ }^{2}$ Virginia Natural Heritage Program, 8 Radford Street, Christiansburg, VA 24073, Wil.Orndorff@dcr.virginia.gov
}

Journal of Cave and Karst Studies, December 2009•193 


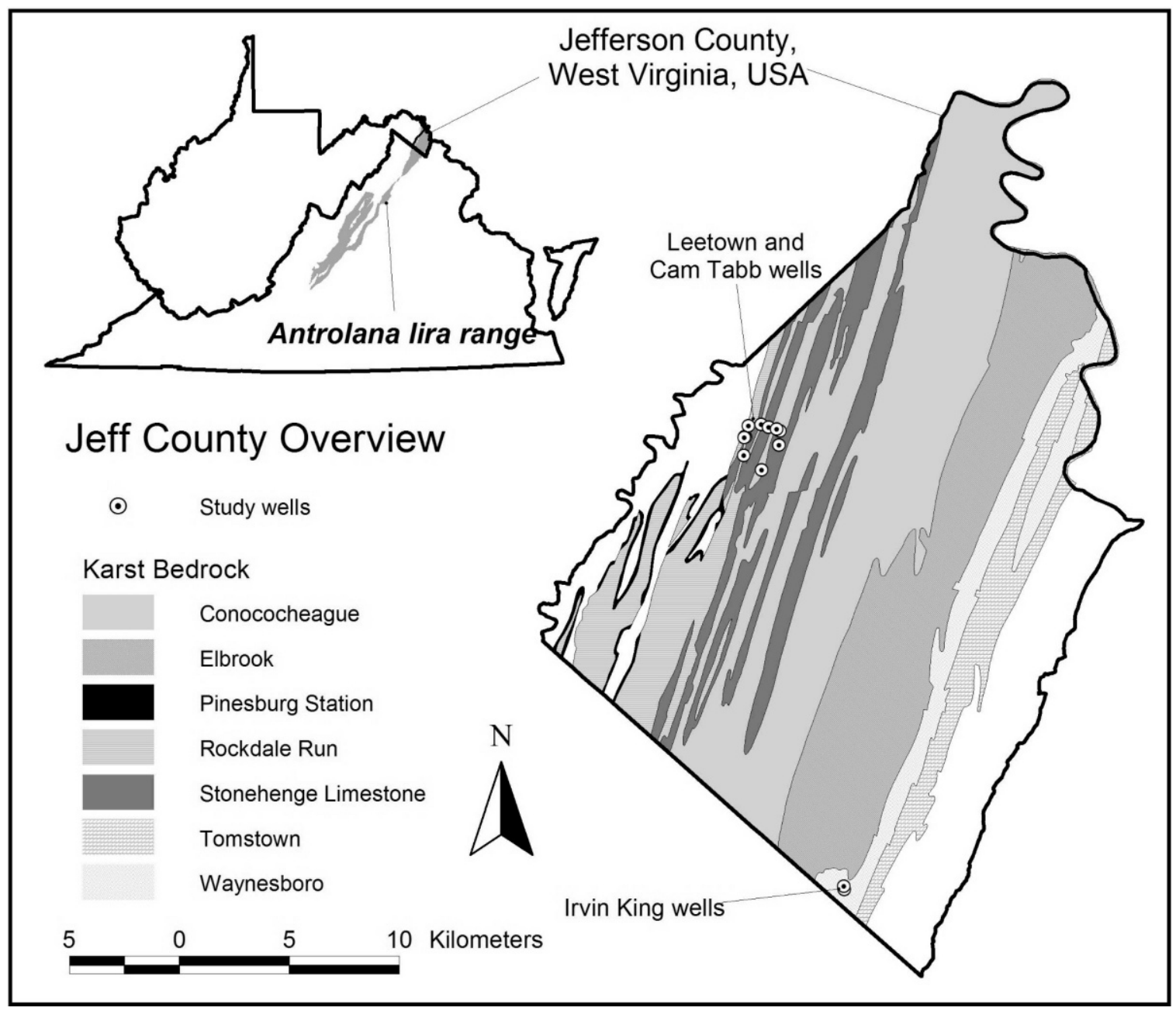

Figure 1. Project location with wells and geology.

wells can be important sampling sites for stygobionts inhabiting the phreatic zone (the saturated zone) in many types of aquifers, including karst (Allford et al., 2008; Culver and Sket, 2000; Eberhart et al., 2007; Hershler and Longley, 1986; Holsinger and Longley, 1980; Malard et al., 1997; Malard and Simon, 1997; Watts and Humphreys, 2003). For carnivorous taxa including amphipods, isopods, and planarians, baited traps can be used (Ginet and Décou, 1977) as an effective and inexpensive, albeit qualitative, sampling method. Wells are more easily accessed than groundwater in caves and are, in some areas, more numerous. This is especially true for the northern Shenandoah Valley, where surface expression of karst is minimal and few known caves extend to the water table.

In 2000, a population of the phreatic stygobiont crustacean Antrolana lira was discovered in a small cave in Jefferson County, West Virginia, extending the known range of the federally threatened species $50 \mathrm{~km}$ to the northeast. Potential degradation of the phreatic aquifer in this region has prompted concern from the U.S. Fish and Wildlife Service, but baseline ecological data, such as distribution, are needed to assess risk and implement recovery recommendations developed for the species (Fong, 1996).

Here, we present the results of a well sampling effort in Jefferson County, West Virginia, at the north end of $A$. lira's range. This effort included one sampling event in May 2005, one in July 2006, and several over a threemonth period during the summer of 2007. Results are used to assess the effectiveness of well sampling for determining presence or absence for $A$. lira. The proportion of wells that intersect habitat where $A$. lira is present was calculated, along with $95 \%$ confidence intervals. Furthermore, the probability of capturing $A$. lira at wells where the species is present was also calculated, along with associated $95 \%$ confidence intervals. Several wells were sampled simultaneously at multiple depths corresponding to water-bearing fractures or voids to investigate the vertical distribution of the species in these wells. At one well, animals were marked and recaptured to estimate population size. These data are used to develop some preliminary guidelines for future well sampling in other parts of the species range and for efforts targeting other species. 


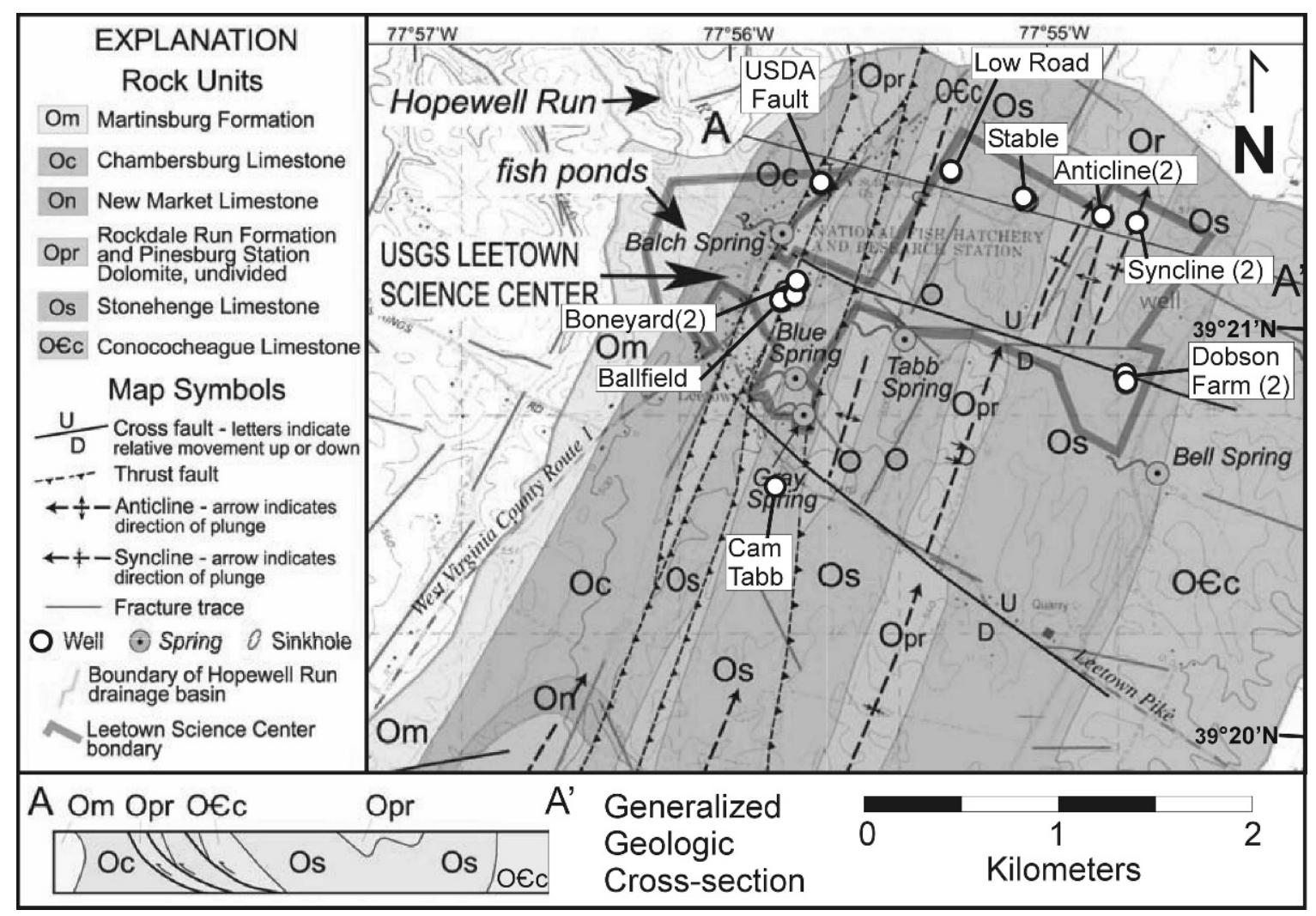

Figure 2. Leetown Science Center wells with topography and geology (modified from Kozar et al., 2007a).

\section{Methods}

\section{SAmpling Methodology}

Seventeen wells were sampled between July 1, 2007, and September 3, 2007. Four of these wells were sampled a single time, and the remaining thirteen wells were sampled between two and seven times. Data from a single sampling event in May 2005 and another in July 2006 were also used for analysis. Wells were located in the karst of Jefferson County, West Virginia, on private property or federal land (Fig. 1). The study area lies within a single contiguous habitat block, here defined as a block of carbonate bedrock bounded by a combination of non-carbonate rocks and base-level streams receiving discharge from the aquifer. The contiguous habitat block involved in this study is bounded to the east and south by the Shenandoah River, to the north by the Potomac River, and to the west by the Martinsburg shale. Analysis of the mitochondrial $\mathrm{CO} 1$ gene in Antrolana lira by Hutchins et al. (2010, in press) showed that animals from sites distributed across this bedrock block constitute a single genetic population. Three types of wells were sampled: hand-dug wells, potential production wells, and monitoring wells. Hand-dug wells were usually wide ( $1 \mathrm{~m}$ or more in diameter) and shallow (less than $10 \mathrm{~m}$ deep). Potential production wells and monitoring wells had $\sim 15$-cm-diameter well casings. All but two of the wells were located on or immediately adjacent to the USGS Leetown Science Center in west-central
Jefferson County (Fig. 2) and had been the subject of prior intensive geohydrological investigations (Kozar et al., 2007a; Kozar et al., 2007b). This earlier work provided an unusual amount of detail in terms of the physical characteristics, hydrological properties, and geological setting of the wells used in this study, as summarized in Table 1.

Wells were sampled with a baited trap modified from Boutin and Boulanouar (1983). Baited traps were chosen for this study because they have a history of effective recovery of A. lira, as well as numerous other crustacean stygobionts (Collins and Holsinger, 1981; Fong, 2007). Traps were constructed using a 23-cm-long, 1.54-cm-diameter PVC pipe with a cap at the bottom. This narrow design was less likely to get lodged in the well than wider designs. Eight 8-mm holes were drilled around the top six inches of the trap. A piece of raw shrimp, wrapped in pantyhose to minimize ingestion by stygobionts, was used as bait. Traps were lowered into wells using kite string or nylon cord. A surveying tape was used to lower traps to arbitrary depths or to depths corresponding to water-bearing fractures identified in Kozar et al. (2007b). Traps were left for 20 to 28 hours. After animals were counted and possibly marked, they were released using a "release trap" made from a short length of 1.54-cm-diameter PVC pipe (Fig. 3). A piece of panty hose was secured around the bottom opening in the pipe using a rubber band. At the other end, a string was attached for lowering the trap into the well. Traps were

Journal of Cave and Karst Studies, December 2009•195 
Table 1. Characteristics of wells sampled in study (adapted from Kozar et al, 2007b).

\begin{tabular}{lrccccrrr}
\hline Well Name & $\begin{array}{c}\text { Depth, } \\
\mathrm{m}\end{array}$ & Geology & $\begin{array}{c}\text { Thickness, } \\
\mathrm{m}\end{array}$ & $\begin{array}{c}\text { Regolith } \\
\text { Thickness, } \\
\mathrm{m}\end{array}$ & $\begin{array}{c}\text { Top of } \\
\text { Bedrock, } \\
\mathrm{m}\end{array}$ & $\begin{array}{c}\text { Casing } \\
\text { Depth, } \\
\mathrm{m}\end{array}$ & $\begin{array}{c}\text { Well } \\
\text { Diameter, } \\
\mathrm{m}\end{array}$ & $\begin{array}{c}\text { Yield, } \\
\text { L min }\end{array}$ \\
\hline Lower Road & 125 & $\mathrm{SH}$ & 6.7 & 1.2 & 7.9 & 11.3 & 15.24 & 68 \\
Stable Piez & 14 & $\mathrm{SH}$ & 3.8 & $\mathrm{~N} / \mathrm{A}$ & 3.8 & 11.3 & 7.62 & 132 \\
Ball Field & 49 & $\mathrm{RR}$ & 3.0 & 0.0 & 3.0 & 11.7 & 15.24 & 19 \\
Ball Field Piez & 0 & $\mathrm{RR}$ & $\ldots$ & 0.0 & $\ldots$ & $\ldots$ & 15.24 & $\ldots$ \\
Boneyard Upper & 34 & $\mathrm{RR}$ & 4.3 & 0.0 & 4.3 & 13.1 & 15.24 & 151 \\
Boneyard Lower & 28 & $\mathrm{RR}$ & 3.0 & 2.0 & 5.0 & 5.8 & 15.24 & 379 \\
Cam Tabb & $\sim 10$ & $\mathrm{SH}$ & $\ldots$ & $\ldots$ & $\ldots$ & $\mathrm{N} / \mathrm{A}$ & $>100$ & $\ldots$ \\
USDA Fault & 61 & $\mathrm{RR}$ & 1.2 & 0.0 & 1.2 & 29.9 & 15.24 & 1135 \\
Syncline & 67 & $\mathrm{RR}$ & 3.7 & 4.9 & 8.5 & 28.3 & 15.24 & 1135 \\
Syncline Piez & 24 & $\mathrm{RR}$ & 5.0 & 0.5 & 5.5 & 18.0 & 7.62 & 379 \\
Anticline & 79 & $\mathrm{RR}$ & 6.1 & 1.5 & 7.6 & 11.7 & 15.24 & 76 \\
Anticline Piez & 13 & $\mathrm{RR}$ & 7.3 & 0.0 & 7.3 & 9.4 & 7.62 & 26 \\
Irvin King \#1 & 53 & $\mathrm{WE}$ & $\ldots$ & $\ldots$ & $\ldots$ & $\ldots$ & 15.24 & 38 \\
Irvin King \# & 38 & $\mathrm{WE}$ & $\ldots$ & $\ldots$ & $\ldots$ & $\ldots$ & 15.24 & 57 \\
Old Dodson & 19 & $\mathrm{SH}$ & $\ldots$ & $\ldots$ & $\ldots$ & 6.1 & 15.24 & $\ldots$ \\
New Dodson & 51 & $\mathrm{SH}$ & $\ldots$ & $\ldots$ & $\ldots$ & 11.7 & 15.24 & $\ldots$ \\
\hline
\end{tabular}

Geology: SH - Stonehenge Formation, RR - Rockdale Run Formation, WE -Waynesboro-Elbrook Formations

lowered slowly through the water column until reaching the approximate depth at which the animals were captured, at which point the trap was repeatedly lifted and dropped (causing water to flow through the pipe, dislodging the panty hose and the animals).

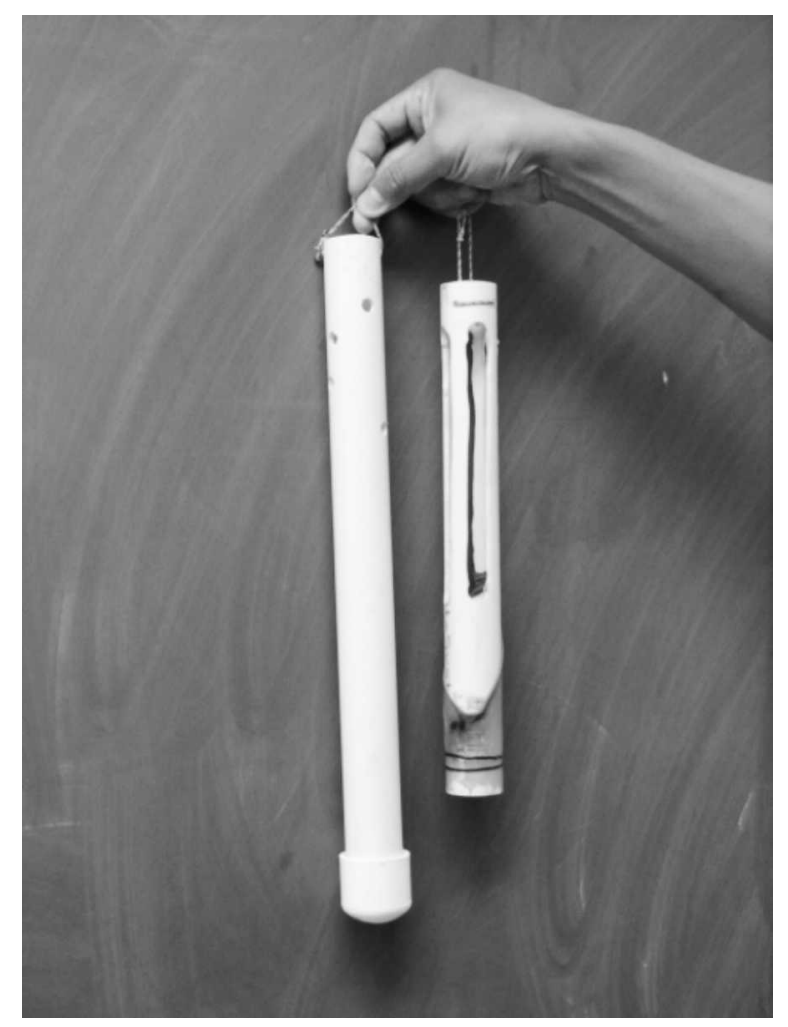

Figure 3. Capture and release traps.

\section{Capture Probabilities}

Data on the capture rates of $A$. lira were used to estimate both the success rate at wells where $A$. lira was captured at least once and the proportion of wells in the contiguous habitat block that intersect habitat where $A$. lira are present. Days when multiple traps were used in a single well at different depths were treated as single sampling events, with capture of $A$. lira in one or more traps constituting a positive result.

By approximating capture data as a binomial approximation to the normal distribution, the standard deviation $\sigma_{p}$ of capture rates was calculated using

$$
\sigma_{p}=\sqrt{\frac{p(1-p)}{n}}
$$

where $n$ is the number of trials and $p$ is the success rate (Lichter, 1999). Standard deviation $\sigma$ was then used to approximate $95 \%$ confidence intervals $(p \pm 2 \sigma$, Ott and Longnecker, 2001).

The probability of capture during a single sampling event at a well $n$ in an area where a target species is present was calculated by

$$
P_{\text {capture }, n}=P_{\text {habitat }, n} \times P_{\text {success }, n}
$$

where $P_{\text {habitat }}$ is the probability that the well intersects habitat where $A$. lira is present, and $P_{\text {success }}$ is the probability that a single sampling event in a well that intersects such habitat will result in capture. The standard deviation of the product was calculated using conventional error-propagation calculations as described in Lichten (1998).

The minimum number of sampling events $T$ needed to determine if the species was present in an individual well 
Table 1. Extended.

\begin{tabular}{|c|c|c|c|c|c|c|c|c|c|c|}
\hline & & & & & & \multicolumn{5}{|c|}{ Depth to Water $(7 / 2003-10 / 2005)$} \\
\hline & \multicolumn{5}{|c|}{ Depths to Water Bearing Features, $m$} & Mean & S.D. & Min. & Max. & Range \\
\hline 35.1 & 113.4 & 121.6 & $\cdots$ & $\cdots$ & $\cdots$ & 14.1 & 0.50 & 12.8 & 14.8 & 2.0 \\
\hline$\ldots$ & $\ldots$ & $\ldots$ & $\ldots$ & $\ldots$ & $\ldots$ & 10.5 & 0.85 & 8.8 & 11.7 & 2.9 \\
\hline 10.7 & $\ldots$ & $\ldots$ & $\ldots$ & $\ldots$ & $\ldots$ & 6.0 & 0.53 & 4.7 & 7.2 & 2.5 \\
\hline$\ldots$ & ... & $\ldots$ & $\ldots$ & $\ldots$ & $\ldots$ & $\ldots$ & $\ldots$ & $\ldots$ & $\ldots$ & $\ldots$ \\
\hline 16.8 & 20.4 & $\ldots$ & $\ldots$ & $\ldots$ & $\ldots$ & 6.3 & 0.37 & 5.5 & 7.1 & 1.7 \\
\hline 10.4 & 14.9 & 19.8 & 21.6 & 23.8 & $\ldots$ & 5.5 & 0.41 & 4.6 & 6.5 & 1.9 \\
\hline$\ldots$ & $\ldots$ & $\ldots$ & & $\ldots$ & $\ldots$ & ... & ... & ... & $\cdots$ & $\ldots$ \\
\hline 9.4 & 14.3 & 18.6 & 35.1 & 39.9 & 47.2 & 5.2 & 0.28 & 4.7 & 6.0 & 1.2 \\
\hline 12.5 & 31.1 & 43.3 & $\ldots$ & $\ldots$ & $\ldots$ & 4.3 & 1.02 & 2.4 & 6.1 & 3.6 \\
\hline 7.6 & 21.3 & $\ldots$ & $\ldots$ & $\ldots$ & $\ldots$ & 3.3 & 0.97 & 3.6 & 7.1 & 3.5 \\
\hline 8.8 & 41.8 & 51.8 & 76.2 & $\ldots$ & $\ldots$ & 5.9 & 0.99 & 4.1 & 7.6 & 3.5 \\
\hline 7.3 & $\ldots$ & $\ldots$ & $\ldots$ & $\ldots$ & $\ldots$ & 5.5 & 0.97 & 3.6 & 7.1 & 3.5 \\
\hline$\cdots$ & $\cdots$ & $\cdots$ & $\ldots$ & $\cdots$ & $\cdots$ & $\cdots$ & $\ldots$ & $\cdots$ & $\cdots$ & $\ldots$ \\
\hline$\cdots$ & $\cdots$ & $\cdots$ & $\ldots$ & $\cdots$ & $\ldots$ & $\cdots$ & $\cdots$ & $\cdots$ & $\cdots$ & $\cdots$ \\
\hline$\ldots$ & $\ldots$ & $\ldots$ & $\ldots$ & $\ldots$ & $\ldots$ & 2.7 & 0.54 & 1.7 & 4.3 & 2.5 \\
\hline$\cdots$ & $\cdots$ & $\cdots$ & $\cdots$ & $\cdots$ & $\cdots$ & $\ldots$ & $\ldots$ & $\ldots$ & $\ldots$ & $\ldots$ \\
\hline
\end{tabular}

and the number of wells $W$ that needed to be sampled to determine if the species was present in an area were calculated from the probability of encountering all negative results after a number of trials $N$ using

$$
P_{n e g, N}=\left(1-P_{p o s}\right)^{N}
$$

where $P_{\text {neg, } N}$ is the probability of all negative results after $N$ trials and $P_{p o s}$ is the probability of a positive result (assumed constant) for any individual trial. For multiple sampling events at a single well, $N=T$ and $P_{\text {pos }}=P_{\text {success }}$. For a single sampling event at multiple wells in a contiguous habitat block, $N=W$ and and $P_{\text {pos }}=P_{\text {capture }}$. When $P_{\text {neg, } N}=0.05$ after $\mathrm{N}$ trials, this means there is only a $5 \%$ chance of no positive results (i.e., a false negative) if a species was present in an area. Conversely, this means that there is a $95 \%$ chance that all negative results after $N$ trials constitutes a true negative, in our case, no animals present. Plugging in the certainty value of 0.05 and solving for $N$ produces

$$
N=\frac{\ln (0.05)}{\ln \left(1-P_{\text {pos }}\right)}
$$

In general, a species may be absent from a well either because it is not present in the area or because the well does not intersect appropriate habitat. Since this study was confined to a contiguous habitat block where the species is present, a consistently negative result within any individual well most likely reflects a failure to intersect appropriate habitat.

\section{Vertical Distribution}

Eight wells were chosen to study the vertical distribution of $A$. lira based on their water yields and the existence of data on the depths of water-bearing fractures or voids (Kozar et al., 2007b). Depending on the number of reported water bearing features in each well, from two to six traps were placed at depths corresponding to these features. In addition to these eight wells, four wells for which no data about water bearing voids was known (Irvin King \#1, Irvin King \#2, Old Dodson, New Dodson) were sampled. For these wells, traps were placed at $7.6-\mathrm{m}$ intervals starting at the bottom of the well.

\section{Population-Size Estimation}

At one well, animals were marked and recaptured to estimate population size. Trapped animals were stored in cool spring water on site for mark and release. To mark animals, we first patted the animal's dorsal surface with a napkin before using a Sharpie brand marker to make an identifiable mark. Population size was estimated using a weighted mean method (Begon, 1979). This method is similar to the traditional Peterson estimate, but employs data from more than one sampling event and uses the equation

$$
\hat{N}=\frac{\sum n_{i} M_{i}}{\sum m_{i}+1}
$$

where $n_{i}$ is the number of individuals caught on sampling day $i, m_{i}$ is the number of individuals collected on day $i$ that are already marked. $M_{i}=\left(r_{2}-m_{2}\right)+\left(r_{3}-m_{3}\right) \ldots+\left(r_{i}-m_{i}\right)$, where $r_{i}$ represents the total number of animals marked and released on the indicated days, including those captured that had 
EFFECTIVENESS AND ADEQUACY OF WELL SAMPLING USING BAITED TRAPS FOR MONITORING THE DISTRIBUTION AND ABUNDANCE OF AN AQUATIC SUBTERRANEAN ISOPOD

Table 2. Summary of sampling results for Madison Cave Isopod (Antrolana lira).

\begin{tabular}{|c|c|c|c|c|c|c|c|c|c|}
\hline Site Name & $5 / 5 / 2005$ & $7 / 8 / 2006$ & $7 / 1 / 2007$ & $7 / 8 / 2007$ & $7 / 15 / 2007$ & $7 / 29 / 2007$ & $8 / 17 / 2007$ & $8 / 26 / 2007$ & $9 / 3 / 2007$ \\
\hline Lower Road Well & 0 & $\cdots$ & 0 & $\cdots$ & $\cdots$ & $\cdots$ & $\cdots$ & $\cdots$ & $\cdots$ \\
\hline Stable Piezometer & 0 & $\cdots$ & 0 & $\cdots$ & $\cdots$ & $\cdots$ & $\cdots$ & $\cdots$ & $\cdots$ \\
\hline Ball Field Well ${ }^{\mathrm{a}}$ & 1 & $\cdots$ & $\cdots$ & 0 & $\cdots$ & $\cdots$ & 0 & 0 & $\cdots$ \\
\hline Ball Field Piezometer & $\cdots$ & $\cdots$ & 0 & $\cdots$ & $\cdots$ & $\cdots$ & $\cdots$ & $\cdots$ & $\cdots$ \\
\hline Boneyard Upper Well & $\cdots$ & $\cdots$ & 0 & $\cdots$ & $\cdots$ & $\cdots$ & $\cdots$ & $\cdots$ & $\cdots$ \\
\hline Boneyard Lower Well & $\cdots$ & $\cdots$ & 0 & $\cdots$ & $\cdots$ & $\cdots$ & $\cdots$ & $\cdots$ & $\cdots$ \\
\hline Cam Tabb Well ${ }^{\mathrm{a}}$ & $\cdots$ & 68 & 1 & 7 & 1 & $\cdots$ & 2 & 2 & 5 \\
\hline USDA Fault Well ${ }^{\mathrm{a}}$ & 0 & $\ldots$ & 0 & $\cdots$ & $\ldots$ & 2 & 1 & $\cdots$ & $\cdots$ \\
\hline Syncline Well ${ }^{\mathrm{a}}$ & 0 & $\cdots$ & 2 & 1 & 0 & 1 & 0 & 1 & $\cdots$ \\
\hline Syncline Piezometer & $\cdots$ & $\cdots$ & 0 & $\cdots$ & $\cdots$ & 0 & $\cdots$ & $\cdots$ & 0 \\
\hline Anticline Well & 0 & $\cdots$ & 0 & $\cdots$ & $\cdots$ & 0 & $\cdots$ & 0 & 0 \\
\hline Anticline Piezometer & $\cdots$ & $\cdots$ & $\cdots$ & $\cdots$ & $\cdots$ & $\cdots$ & $\cdots$ & $\cdots$ & 0 \\
\hline Irvin King \#1 Wella & $\cdots$ & 0 & $\cdots$ & $\cdots$ & $\cdots$ & $\cdots$ & $\cdots$ & 0 & 2 \\
\hline Irvin King \#2 Well ${ }^{\mathrm{a}}$ & $\cdots$ & 20 & 8 & 20 & 13 & 12 & 9 & $\cdots$ & $\cdots$ \\
\hline Old Dodson Well & 0 & $\cdots$ & $\cdots$ & 0 & $\cdots$ & $\cdots$ & $\cdots$ & 0 & 0 \\
\hline New Dodson Well & $\cdots$ & $\cdots$ & $\cdots$ & 0 & $\cdots$ & $\cdots$ & $\cdots$ & 0 & 0 \\
\hline
\end{tabular}

${ }^{a}$ Captured well.

previously been marked. The standard error is calculated using

$$
S E_{\hat{N}}=\hat{N} \sqrt{\frac{1}{\sum m_{i}+1}+\frac{2}{\left(\sum m_{i}+1\right)^{2}}+\frac{6}{\left(\sum m_{i}+1\right)^{3}}}
$$

\section{RESULTS}

Fifty-four sampling events were performed at a total of 18 wells (Table 2). Six wells, referred to as capture wells, yielded Antrolana lira at least once. The physical and hydrological characteristics of these wells are summarized in Table 1. Of all the sampling events at capture wells, individuals were captured 21 out of 31 sampling events $(68 \%)$. Ten wells were sampled between three and seven times to accumulate data on the temporal variation in the presence and abundance of species collected. Table 2 shows results of all sampling events performed during this study. Days when multiple traps were placed in a well on the same day were treated as a single sampling event. Figure 4 illustrates the variation over time of capture rates at each well in which Antrolana was captured at least once.

Positive capture rates at wells where $A$. lira was captured at least once ranged from $25 \%$ to $100 \%$. In the two wells with relatively high numbers of individuals, Cam Tabb and Irvin King \#2, A. lira was present $100 \%$ of the time. In the other four capture wells, a maximum of two animals were captured during any single sampling event. Furthermore, each of these wells had at least one sampling event in which no animals were captured.

\section{Capture Probability Results}

The probability of success at capture wells was estimated at $P_{\text {success }}=0.68 \pm 0.08$, with $95 \%$ confidence intervals of $0.51<P_{\text {success }}<0.85$. Applying Equation (4) to the results for $P_{\text {success }}$, the minimum number of sampling events at a well to determine whether it intersects habitat, based on successful capture during one or more event, is three $(T=$ $2.63)$ using the predicted value of $P_{\text {success, }}$, and five $(T=4.2)$ based on the lower end of the $95 \%$ confidence interval. The criteria for use of the binomial approximation as described in Ott and Longnecker (2001) are met for $P_{\text {success }}$.

Wells within the study area sampled three or more times can then be used to estimate the habitat intersection rate $P_{\text {habitat }}$. A. lira was captured at least once in 6 of the 10 wells sampled 3 or more times, resulting in $P_{\text {habitat }}=0.60 \pm$ 0.16 . Within $95 \%$ confidence limits, $0.29<P_{\text {habitat }}<0.91$.

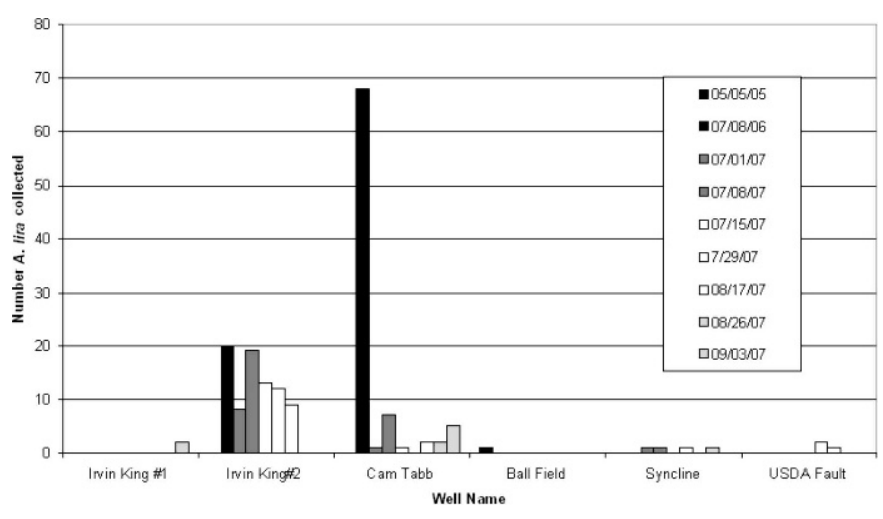

Figure 4. Capture rate variation at wells where Antrolana lira was collected at least one time. 
Table 3. Vertical distribution of Madison Cave Isopod (Antrolana lira) in wells.

\begin{tabular}{lccccc}
\hline & & \multicolumn{4}{c}{$\begin{array}{c}\text { Number of Individuals by Date } \\
\text { Sampled }\end{array}$} \\
\cline { 3 - 6 } Well Name & $\begin{array}{c}\text { Depth } \\
\text { (m) }\end{array}$ & $\begin{array}{c}7 / 29 / \\
\text { USDA Fault }\end{array}$ & $8 / 17 /$ & $8 / 26 /$ & $9 / 3 /$ \\
& 9 & 0 & 0 & $\ldots$ & $\ldots$ \\
& 14 & 0 & 0 & $\ldots$ & $\ldots$ \\
& 19 & 0 & 0 & $\ldots$ & $\ldots$ \\
Syncline & 35 & 2 & 0 & $\ldots$ & $\ldots$ \\
& 40 & 0 & 1 & $\ldots$ & $\ldots$ \\
Irvin King \#1 & 47 & 0 & 0 & $\ldots$ & $\ldots$ \\
& 12 & 0 & 0 & 0 & $\ldots$ \\
Irvin King \#2 & 31 & 1 & 0 & 1 & $\ldots$ \\
& 43 & 0 & 0 & 0 & $\ldots$ \\
& 24 & $\ldots$ & $\ldots$ & 0 & 0 \\
& 37 & $\ldots$ & $\ldots$ & 0 & 2 \\
& 23 & 0 & 0 & $\ldots$ & $\ldots$ \\
& 30 & 0 & 0 & $\ldots$ & $\ldots$ \\
& 38 & 10 & 0 & $\ldots$ & $\ldots$ \\
& 44 & 2 & 9 & $\ldots$ & $\ldots$ \\
\hline
\end{tabular}

Applying Equation (4), the minimum number of wells necessary to sample to ensure intersection of habitat is four ( $W=3.27$ ) for the predicted value of $P_{\text {habitat }}$, and nine at the lower end of the $95 \%$ confidence interval $(W=8.75)$. The low number of wells (ten) sampled enough times to determine $P_{\text {habitat }}$ limits the significance of these numbers, because the criteria for use of the binomial approximation, as described in Ott and Longnecker (2001), are not met.

Applying Equation (2), the probability of capture $P_{\text {capture }}$ for a single sampling event at a single well within the study area is $0.41 \pm 0.12$. Within $95 \%$ confidence limits, $0.17<\mathrm{P}_{\text {capture }}<0.65$. High standard deviation and large confidence intervals are a result of the low number (ten) of wells sampled three or more times combined with the propagation of uncertainty in $P_{\text {success }}$ and $P_{\text {habitat }}$. For the calculated $P_{\text {capture }}$ of 0.41 , the corresponding minimum number of unique sampling events (individual wells sampled one time each) necessary to determine whether the species is present in a contiguous phreatic habitat block such as the study area is six $(N=5.68)$. However, if the lower end of the $95 \%$ confidence interval is used, the minimum number of trials for such a determination increases to sixteen $(N=16.07)$.

\section{Vertical Distribution Results}

Table 3 shows the dates and depths at which individual wells were sampled at multiple levels and when and at what level individuals of $A$. lira were recovered. Four of those wells yielded $A$. lira. In USDA Fault Well, A. lira was
Table 4. Mark recapture data for Irvin King \#2 well.

\begin{tabular}{lccc}
\hline & \multicolumn{3}{c}{$\begin{array}{c}\text { Number of Individuals by Date } \\
\text { Sampled }\end{array}$} \\
\cline { 2 - 4 } Variable & $7 / 1 / 2007$ & $7 / 8 / 2007$ & $7 / 15 / 2007$ \\
\hline Number captured, $n$ & 8 & 19 & 13 \\
Number marked, $m$ & $\ldots$ & 2 & 3 \\
$\begin{array}{c}\text { Number marked and } \\
\text { released, } r\end{array}$ & 8 & 19 & 13 \\
\hline
\end{tabular}

found at water-bearing horizons at $35 \mathrm{~m}$ and $40 \mathrm{~m}$. In Syncline Well, A. lira was collected from traps at the 31-m water-bearing horizon during four out of six sampling events, while horizons at $12 \mathrm{~m}$ and $43 \mathrm{~m}$ yielded no individuals. Irvin King \#2 yielded multiple individuals at depth of $38 \mathrm{~m}$ and $44 \mathrm{~m}$, and no animals at 23-m and 30-m depths. Irvin King \#1 yielded individuals at a depth of $24 \mathrm{~m}$. On average, $A$. lira was collected from $31 \% \pm 4 \%$ of water-bearing horizons in each of these four wells.

\section{Population Size Estimation Results}

Marked animals were only recaptured at Irvin King Well \#2, and consequently, population size could not be estimated at other locations. At Irvin King Well \#2, animals were captured, marked, and released on July 1, July 8, and July 15, 2007. Table 4 summarizes the data used to calculate the population estimate and uncertainty using Equations (4) and (5). The limited population being sampled at Irvin King Well \#2 only allowed a very rough estimate of 112.3 individuals $\pm 110(95 \% \mathrm{CI})$.

\section{Discussion}

\section{Capture Probability Discussion}

While it is clear that well sampling using baited traps is an effective way to sample for stygobiont crustacean fauna such as the Madison Cave isopod Antrolana lira, interpretations of results must be performed conservatively and with caution. At least three conditions must be met for a successful capture. First, the sampling site must be within the range of the species. Second, the well must intersect appropriate habitat, in this case interconnected, permeable voids beneath the water table that are large enough to be traversable by the species. Finally, the trap must effectively attract and retain animals. The efficiency with which a particular sampling method attracts and retains animals must also be considered when comparing data from multiple sampling methods. Allford et al. (2008) tested three different sampling methods on wells in the Yilgarn region of Australia and found differences in the number of species and total number of individuals collected, but no significant difference in the relative probability for capturing a particular species as a function of sampling method.

Journal of Cave and Karst Studies, December 2009•199 
In Leetown, capture wells appear randomly distributed within a contiguous phreatic habitat block, suggesting that the entire study area lies within the potential range of the species. However, within this range, the species is heterogeneously distributed, depending on the presence of favorable habitat, which is patchy but interconnected (Hutchins et al., 2010, in press). The fact that this habitat is hidden from view complicates any sampling strategy. This study seeks to calculate the probability that the last two conditions are met: a given well intersects favorable habitat $\left(P_{\text {habitat }}\right)$ and that the species is collected during the sampling event $\left(P_{\text {success }}\right)$. We found that $P_{\text {habitat }}=0.60 \pm$ $0.31(95 \%$ C.I. $)$ and that $P_{\text {success }}=0.68 \pm 0.17$ (95\% C.I.) for $A$. lira in our study area. These values were used to predict that for a unique sampling event for $A$. lira within the study area the probability of capture is $0.41 \pm 0.12$. (95\% C. I.: $\left.0.17<P_{\text {capture }}<0.65\right)$ and to estimate that approximately six sampling events are necessary to determine if the species is present in a similar contiguous phreatic habitat block (sixteen events if the lower end of the confidence interval is used). Exporting the results to outside the study area assumes that neither $P_{\text {success }}$ nor $P_{\text {habitat }}$ varies significantly from one contiguous phreatic habitat block to another. Unfortunately, enough data points were not collected in the study to tightly constrain the predicted value of $P_{\text {capture }}$ in the study area, although $P_{\text {success }}$ and $P_{\text {habitat }}$ were moderately well constrained. Our results were similar to those of Eberhard et al. (2007), who used net-haul sampling in the Pilbara region of Australia and found detection probabilities for species to average 33 $\pm 5 \%$ or $39 \pm 3 \%$ (two different methods) and that six samples collect $95 \%$ of species present in a well.

For those interested in determining with certainty the absence or presence of a stygobiont in an area, a paucity of sampling locations and low densities of animals presents a high risk of false negatives. Obviously, the best way to reduce this risk is to increase the number of sites sampled and the number of sampling events. However, the number of available sampling sites in a contiguous phreatic habitat block is essentially fixed. This makes desirable a sampling scheme that samples sites on multiple occasions to achieve the desired level of certainty in the presence or absence of a species.

MacKenzie et al. (2002) developed such a technique and applied it to a data-set investigating site occupancy of amphibians in Maryland, USA. Their model considered the probability of the presence of a species at a site, the number of sites, the number of sampling events, and the probability of detection. Such a model could be effectively applied to the stygobiont sampling scenario described in this paper if the probability of the presence of a species was replaced with that of habitat intersection. Unfortunately, the data-set in this study was too small for these methods to be applied.

There was no obvious relationship between physical and hydrological properties of the individual wells (Table 1) and the presence or absence of Antrolana lira. While the two highest-yield wells (Syncline and USDA Fault, each $1135 \mathrm{~L} \mathrm{~min}^{-1}$ ) both yielded specimens, so did low-yield wells such as Irvin King \#1 (38 $\left.\mathrm{L} \mathrm{min}^{-1}\right)$, Irvin King \#2 $\left(57 \mathrm{~L} \mathrm{~min}^{-1}\right)$, and Ball Field (19 $\mathrm{L} \mathrm{min}{ }^{-1}$ ), with Irvin King \#2 being the most consistent producer of $A$. lira. In terms of geology, specimens were successfully captured from at least one well in all formations in which wells were sampled.

Differences in the May 2005, July 2006, and summer 2007 sampling events suggest that groundwater levels may strongly influence sampling success rates, both in terms of numbers and of stygobiont species. This is in contrast with the results of Eberhard et al. (2007), who found no seasonal turnover in faunal composition in sampling wells over a 4year period in the Pilbara region of Western Australia. Figure 5 shows water levels in the aquifer at Leetown Science Center over the period of interest. Both the May 2005 and July 2006 sampling events took place during relatively high groundwater levels, immediately after significant recharge events, while the summer 2007 sampling was performed under drought conditions. In May 2005 the water level was more than a meter higher than in summer 2007, and numerous amphipods were captured in the Old Dodson Farm Well and the Ballfield Well, which also yielded a single Antrolana lira. Neither of these wells yielded a single crustacean specimen during summer 2007 sampling. The July 2006 sampling event at Cam Tabb Well stands out as well. Sixty-eight individuals were collected in that event, compared with a range of 1 to 7 individuals captured during 2007 sampling events, when water levels were approximately $0.6 \mathrm{~m}$ lower than in 2006 . This apparent water-level influence on sampling results may have to do with water levels reaching the elevation of specific conduits, allowing the animals to move within the aquifer. Alternatively, the presence of larger numbers of animals following recharge events may reflect flushing of animals from different hydrological realms in the subsurface. A third possible explanation is that the animals may be more active within the aquifer in response to a higher food supply associated with a recharge event. In any case, these results showed that the probability of successful recovery of $A$. lira at wells that intersected habitat varied both from well to well and at an individual well over time.

\section{Vertical Distribution Discussion}

While the depth sampling did not yield enough data to be conclusive, it did suggest that specific water-bearing horizons are associated with the presence of certain stygobiont species, and that many of these horizons are at considerable depths (up to $\sim 30 \mathrm{~m}$ ) below the water table. During all sampling events in drilled wells, Antrolana lira was only collected in traps placed at least $25 \mathrm{~m}$ beneath the land surface. During July 2007, only traps placed at least $30 \mathrm{~m}$ below the land surface yielded specimens. This does not hold for cave or hand-dug-well collections, neither of which generally allow for the trap to be placed more than $10 \mathrm{~m}$ beneath the water surface. The risk of false 

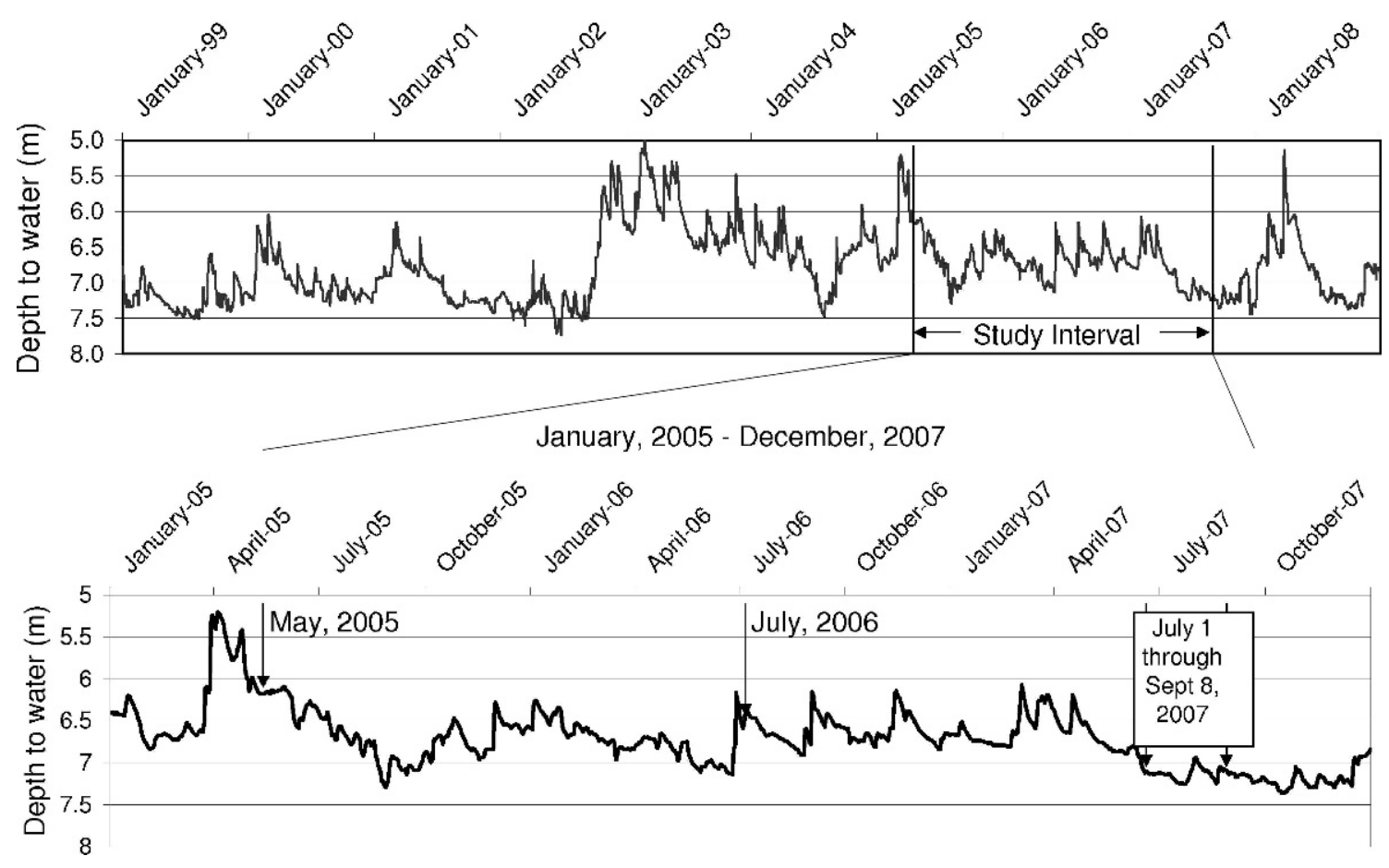

Figure 5. Water levels at Leetown Science Center monitoring wells (USGS, 2009).

negatives for wells is significant, as discussed above, and may be increased when a single trap is placed at an arbitrary depth. However, this risk may be overcome through the use of alternative sampling methods, such as haul nets that sample the entire water column (Allford et al., 2008). Results from Irvin King \#2 Well show that trap level will not affect capture rate in all instances. During the mark-recapture phase of the project, a single trap was placed at an arbitrary depth $(25 \mathrm{~m}$, approximately $6 \mathrm{~m}$ beneath the surface of the water) during weeks one to three, yielding 8, 19, and 13 animals, respectively. During the horizon-sampling phase, traps at $23 \mathrm{~m}$ and $30 \mathrm{~m}$ yielded no specimens, while traps at $38 \mathrm{~m}$ and $44 \mathrm{~m}$ yielded combined totals of 12 and 9 individuals for weeks four and five. This suggests that animals were present at lower levels in the well during the mark-recapture phase and swam up the well to reach the bait. It is likely that the reason they are present lower in the well is that they are closer to the intersection of the well bore with waterbearing voids or fractures (e.g., USDA Fault and Syncline Wells, Table 2). Alternatively, Hahn and Matzke (2005) suggest that detritus and sediment that preferentially accumulates at the bottom of wells may act as habitat islands in aquifers, attracting a higher abundance of taxa than elsewhere in the aquifer. This potential relationship depends strongly on the identity and life history of the species involved.

\section{Population Size Estimation Discussion}

Population size estimation was only possible at one sampling location due to the lack of recaptured specimens elsewhere. At Irvin King Well \#2, $112.3 \pm 110$ individuals were estimated to compose the population sampled during this study. Obviously, this estimation has a large degree of uncertainty. Furthermore, as with other population-size estimation methods, this method makes a variety of assumptions. First, it assumes no births, deaths, immigration, or emigration during the sampling period. This first assumption is probably not significantly violated, given that subterranean organisms have low reproductive potential and metabolic rate and that Antrolana lira has no known predators. This method also assumes that capture and marking does not affect an individual's chance at subsequent capture. In another population size estimation study for A. lira, one week was found to be a sufficient period of time for previously captured and marked animals to be re-trapped (Fong, unpublished data). Finally, the method assumes that all individuals have an equal chance of being caught. Given the heterogeneous nature of phreatic passages, complex flow routes, and the fact that no ovigerous females have ever been captured, this final assumption may be violated in the case of A. lira. Nevertheless, Hahn and Matzke (2005) suggest that taxa may be preferentially distributed near wells that serve as habitat islands, and at least one

Journal of Cave and Karst Studies, December 2009•201 
EFFECTIVENESS AND ADEQUACY OF WELL SAMPLING USING BAITED TRAPS FOR MONITORING THE DISTRIBUTION AND ABUNDANCE OF AN AQUATIC SUBTERRANEAN ISOPOD

mathematical model suggests that vagile taxa such as $A$. lira may be able to travel significant distances within aquifers (Eberhard et al., 2007). What these data do suggest is that this is a small population. This is corroborated by low genetic variability within the site (Hutchins et al., 2010, in press). This has implications for the conservation of the species, because low population size that is potentially clustered near the well puts the population at risk.

The only other population size estimates for A. lira have been performed using identical methods at Cave Hill in Augusta County, Virginia (Fong, 2007). Population size estimates at Cave Hill were much higher than at Irvin King, ranging from 0.36 to $1.02 \times 10^{3}$ at Madison Saltpetre Cave and 2.24 to $3.42 \times 10^{3}$ at Steger's Fissure (Fong, 2007). Population estimates at other documented sites within the range need to be performed to determine what population sizes are more typical for A. lira.

\section{Conclusions}

In some areas, the abundance of wells in proximity to one another relative to that of caves and springs allows for more comprehensive sampling across the potential range of a stygobiont species. Some karst areas, like the lower (northern) Shenandoah Valley, are particularly cave-poor, and wells afford a much better way of accessing habitat. This study has shown that if preliminary sampling efforts are sufficient to constrain the probabilities of habitat intersection and successful recovery of animals, then it is possible to develop a meaningful protocol for sampling wells with baited traps to determine presence or absence of a phreatic stygobiont. The results of such sampling are likely to vary with aquifer water levels and in response to recharge events. Use of wells with comprehensive hydrological and borehole descriptions combined with sampling at discrete depths increased understanding of the three-dimensional subterranean habitat structure. Animals were shown to be present at significant depths (up to $30 \mathrm{~m}$ ) beneath the water table, and they appear to be using specific conduits within the aquifer. Successful completion of a mark-recapture population estimate showed that known populations of Antrolana lira in the northern end of its range are at much lower densities than those at the type locality of Cave Hill. Future research on this topic should include extensive additional sampling within the project area to better constrain detection and habitat intersection probabilities, replication of the study in other contiguous habitat blocks of the Madison Cave isopod to test the assumption that detection and habitat intersection probabilities are relatively constant between such blocks, and application of these methods to other phreatic stygobiont species to determine inter-species variations in detection and habitatintersection probabilities.

\section{AcKnowledgements}

This research was funded by a West Virginia Wildlife Diversity Program grant. Mike Beck, Penelope Pooler, and Walt Pirie served as invaluable sounding boards for the statistical portions of this paper. Special thanks to the USGS Leetown Science Center for allowing use of research wells for this investigation.

\section{REFERENCES}

Allford, A., Cooper, S.J.B., Humphreys, W.F., and Austin, A.D., 2008, Diversity and distribution of groundwater fauna in a calcrete aquifer: Does sampling method influence the story?: Invertebrate Systematics, v. 22 , p. $127-138$.

Begon, M., 1979, Investigating animal abundance: capture-recapture for biologists: London, Edward Arnold, 97 p.

Boutin, C., and Boulanouar, B., 1983, Méthodes de capture de la faune stygobie: Expérimentation de différents types de pièges appâtés dans les puits de Marrakech: Bulletin, Faculty of Science, Marrakech (Section Science de la Vie), v. 2, p. 5-21.

Castellarini, F., Dole-Oliver, M.J., Malard, F., and Gibert, J., 2007, Modeling the distributions of stygobionts in the Jura Mountains (eastern France): Implications for the protection of groundwaters: Diversity and Distributions, v. 13, p. 213-224.

Collins, T.L., and Holsinger, J.R., 1981, Population ecology of the troglobitic isopod crustacean Antrolana lira Bowman (Cirolanidae): Proceedings of the 8th International Congress of Speleology, v. 1, p. 129-132.

Culver, D.C., Christman, M.C., Elliott, W.R., Hobbs, H.H. III., and Reddell, J.R., 2003, The North American obligate cave fauna: regional patterns: Biodiversity and Conservation, v. 12, p. 441-468.

Culver, D.C., and Sket, B., 2000, Hotspots of subterranean biodiversity in caves and wells: Journal of Cave and Karst Studies, v. 62, no. 1, p. $11-17$.

Dole-Oliver, M.J., Castellarini, F., Coineau, N., Galassi, D.M.P., Mori, N., Valdecasas, A., and Gibert, J., 2007, Towards an optimal sampling strategy to assess groundwater biodiversity: Comparison across six European regions: Freshwater Biology, v. 54, no. 4, p. 777-796.

Eberhard, S.M., Halse, S.A., Williams, M.R., Scanlon, M.D., Cocking, J., and Barron, H.J., 2007, Exploring the relationship between sampling efficiency and short-range endemism for groundwater fauna in the Pilbara region, Western Australia: Freshwater Biology, v. 54, no. 4, p. $885-901$.

Fong, D.W., 2007, Mark-recapture populations size estimates of the Madison Cave isopod, Antrolana lira [abs.]: Journal of Cave and Karst Studies, v. 69, no. 3, 360 p.

Fong, D.W., 1996, Madison Cave Isopod (Antrolana lira) Recovery Plan, Hadley, MA, U.S. Fish and Wildlife Service, $32 \mathrm{p}$.

Fong, D.W., Culver, D.C., Hobbs, H.H. III., and Pipan, T., 2007, The invertebrate cave fauna of West Virginia, $2^{\text {nd }}$ ed: West Virginia Speleological Survey Bulletin 16, $163 \mathrm{p}$.

Ginet, R., and Décou, V., 1977, Initiation à la biologie et à l'écologie souterraines: Paris, J.P. Delarge, 345 p.

Hahn, H.J., and Matzke, D., 2005, A comparison of stygofauna communities inside and outside groundwater bores: Limnologica, v. 35, p. $31-44$.

Hancock, P.J., and Boulton, A.J., 2007, Sampling groundwater fauna: Efficiency of rapid assessment methods tested in bores in eastern Australia: Freshwater Biology, v. 54, no. 4, p. 902-917.

Hershler, R., and Longley, G., 1986, Phreatic Hydrobiids (Gastropoda: Prosobranchia) from the Edwards (Balcones Fault Zone) Aquifer region, South-Central Texas: Malacologia, v. 27, no. 1, p. 127-172.

Holsinger, J.R., and Longley, G., 1980, The Subterranean Amphipod Crustacean Fauna of an Artesian Well in Texas: Washington, D. C., Smithsonian Contributions to Zoology no. 308, 62 p.

Hutchins, B., Fong, D.W., and Carlini, D.B., 2010, Genetic Population Structure of the Madison Cave Isopod, Antrolana lira (Flabellifera; Cirolanidae) in the Shenandoah Valley of the eastern United States: Journal of Crustacean Biology, v. 30 (in press).

Kozar, M.D., McCoy, K.J., Weary, D.J., Field, M.S., Pierce, H.A., Schill, W.B., and Young, J.A., 2007a. Geohydrology and water quality of the 
Leetown Area, West Virginia: U.S. Geological Survey Open-file Report 2007-1358, 100 p, http://pubs.usgs.gov/of/2007/1358. [accessed April 14, 2009]

Kozar, M.D., Weary, D.J., Paybins, K.S., and Pierce, H.E., 2007b, Hydrogeologic Setting and Ground-Water Flow in the Leetown Area, West Virginia, U.S. Geological Survey Scientific Investigations Report 2007-5066, 72 p.

Krejca, J., 2004, Inventory of karst fauna in Sequoia, Kings Canyon, and Yosemite National Parks, $2^{\text {nd }}$ Progress Report, National Park Service, 8 p.

Lichten, W., 1998, Data and Error Analysis, Second Edition: Upper Saddle River, New Jersey, Prentice-Hall, 192 p.

MacKenzie, D.I., Nichols, J.D., Lachman, G.B., Droege, S., Royle, J.A., and Langtimm, C.A., 2002, Estimating site occupancy rates when detection probabilities are less than one: Ecology, v. 83, no. 8, p. 2248-2255.

Malard, F., and Simon, K., 1997, Sampling in wells for describing ecological patterns at a microscale in karst aquifers, in Sasowsky, I.D., Fong, D.W., and White, E.L., eds., Conservation and Protection of the Biota of Karst, Charlestown, West Virginia, Karst Water Institute, p. 46-55.

Malard, F., Reygrobellet, J.L., Laurent, R., and Mathieu, J., 1997, Developments in sampling the fauna of deep water-table aquifers: Archiv für Hydrobiologie, v. 138, p. 401-432.

Ott, R.L., and Longnecker, M., 2001, An introduction to Statistical Methods and Data Analysis, Fifth Edition: Pacific Grove, California, Duxbury Press, $1152 \mathrm{p}$.

U.S. Geological Survey, 2009, USGS Real-time water data for West Virginia, Groundwater: U.S. Geological Survey, http://waterdata.usgs. gov/wv/nwis/current/?type $=$ gw\&group_key $=$ county_cd [accessed January 27,2009$]$.

Watts, C.H.S., and Humphreys, W.F., 2003, Twenty-six New Dytiscidae (Coleoptera) of the Genera Limbodessus Guignot And Nirripirti Watts \& Humphreys, from Underground Waters in Australia: Transactions of the Royal Society of South Australia, v. 30, p. 123-185. 